\title{
POSTED WORKERS BETWEEN WORK CASUALISATION AND THE PRECARISATION OF MIGRATION
}

\author{
Fabio PEROCCO
}

COBISS 1.01

\begin{abstract}
Posted Workers between Work Casualisation and the Precarisation of Migration The article examines the transformations of work, labour casualisation, and the precarisation of migration, deepening the links between these phenomena and the social consequences of their intertwining, such as the double precarity affecting migrant workers, and examining the significance of contemporary migration policies which pave the way for a wider spreading of precarity and which anticipate corresponding labour laws. The article - which considers the European context - focuses on posting of workers as an example of the convergence of the aforementioned processes, and an empirical space for social research in which to test new forms of precarity and stratification, and the transformation of migration policies increasingly focused on the concepts of temporariness and circularity.
\end{abstract}

KEY WORDS: precarisation, work transformation, migration, posted workers

\section{IZVLEČEK}

\section{Napoteni delavci med kazualizacijo dela in prekarizacijo migracij}

Članek obravnava spremembe na področju dela, kazualizacije dela in prekarizacije migracij; osvetljuje tako povezave med omenjenimi pojavi kot tudi družbene posledice njihovega prepletanja, npr. dvojno prekarnost migrantskih delavcev. Preučuje tudi pomen sodobnih migracijskih politik, ki vodijo $k$ širjenju prekarnosti in prinašajo temu primerno delavsko zakonodajo. Članek se z obravnavo evropskega konteksta na napotene delavce osredotoča kot na primer konvergence omenjenih procesov, pa tudi kot na empirični prostor družbenega raziskovanja. Ta se ukvarja z novimi oblikami prekariata in razslojenosti ter s transformacijo migracijskih politik, vedno bolj osredotočenih na začasnost in krožnost.

KLJUČNE BESEDE: prekarizacija, spremembe dela, migracije, napoteni delavci

Ph.D. in Sociology, Associate Professor, Foscari University of Venice, Dorsoduro 3484/d, I-30100 Venice; fabio.perocco@unive.it 


\section{INTRODUCTION}

Within the deep and turbulent process of social transformation which has taken place at global level over the last three decades, a leading role has been played by work transformations and the globalisation of migrations, both at the core of public debates and political agendas. As for the former, one of the most debated aspects in the past twenty years is labour flexibility, which has attracted many champions and as many critics. As for the latter, more attention has been paid to the fact that immigration has to respond strictly to the needs of receiving countries and to be useful to their economic systems; some believe temporary migration should be supported, resorting to migrant workers on a just-in-time model, while others believe the rights of workers should be protected.

This article examines the casualisation of work and the precarisation of migration - in the context of significant transformations of work - deepening the links between these events and the social consequences of their interconnection. Work casualisation and the precarisation of migration have developed somewhat independently and differently with respect to the historical and geographical contexts, yet at the same time they have combined and intertwined, often going hand in hand. In their convergence they have produced specific social issues (such as double precarity in the labour and legal spheres, which affects numerous migrant workers) and "new" social phenomena such as agreements on and activities designed to promote circular migration.

With respect to the European context, the first section examines the transformation of work and of the global labour market and its impact on international migration, citing the example of migrant workers in the system of subcontracting. The second section analyses the process of the structural casualisation of work, highlighting how it is now in a quite extreme phase, which mainly affects migrant workers - who in turn are an enlargement vector for casualisation, an experimental workshop for new forms of precarisation which are later extended to other workers. The third section focuses on the precarisation of migration, considering the return of temporary migrations and the scope of the combination of migration and labour policies which pave the way for the further enlargement of precarity. The fourth section focuses on posted workers as an example of the convergence of the aforementioned processes. From a global perspective, posted workers are a precarious and compressed segment of the global labour market, an empirical space for social research where we can examine new forms of precarisation, the alteration of social citizenship, the stratification of social rights, and new migration policies increasingly focused on the concept of temporariness. 


\section{GLOBAL TRANSFORMATIONS OF WORK}

One of the cornerstones of the great social restructuring of the past three decades is the wide-ranging and profound transformation of the labour market and of the organization of work (Antunes 2013; Doogan 2009; Head 2003; Huws 2014), which is a composite yet unitary process.

In the wake of the centuries-old process of creation of the global market, today's labour market is fully global. The globalisation of capitalism and the spreading of industrialisation at global level have led to the unification of the global labour market within the global market as a whole. This unification - stratified and unequal - has taken place alongside a profound transformation of the international division of labour, which, due to delocalisation and international migrations, is very different today compared to the past centuries and decades, when the Western world controlled production and trade while the countries from the Global South supplied raw materials and low-cost workforce. These processes have dictated wider and tougher competition among workers at global level, with the presence of new situations, such as the posting of workers: in this framework, posted workers - a sort of delocalisation in situ - are a precarious and compressed segment of the global labour market.

The transformations of work organization, accelerated by the recent global crisis, have been deep and manifold. In addition to the systematic application of informatics and robotics to the production process, ${ }^{1}$ a leading role has been played by organizational flexibility, i.e. the set of methods - from lean production to outsourcing, from just-in-time to new management - which have produced, under Toyotism, the fragmentation and acceleration of production processes, which are increasingly "lyophilized" (Antunes 2008).

One structural element and a symbol of the new forms of division and organization of work - and which is a massive source of employment for migrant workers, including posted workers - is subcontracting (Huws, Podro 2012; Weil 2014). The growth of subcontracting in the last few decades has taken place in the wake of the global spreading of outsourcing and has played a leading role in the transformation of production, in the organisation of global commodity chains, and in lowering the costs of production - especially the cost of labour. Today, subcontracting is a part of all production sectors, in most of the world, in the public and private sector, and it is no exaggeration to talk about the globalisation of the subcontracting system. Its expansion and consolidation are due to several factors, including the application of lean production in subcontracting and the embedding among private and public companies of the "do not hire" principle - which is now a universal dogma in contemporary political economy and has favoured the general dissemination of

1 Which has often led to the increased polarization of work and the de-skilling of a number of workers (Ford 2015). 
temporary work. The demand for outsourcing and subcontracting on one hand and the demand for temporary work on the other have found in migrant workers and posted workers the ideal combination to have a just-in-time "zero waste" workforce, to extract value from migrant workers while eliminating the restrictions and social costs deriving from their establishing roots in the country, without having to pay the so-called "immigration costs".

The intertwining of the fragmentation of production, the hierarchization of labour, and the differentiation in working conditions which characterise the subcontracting system is the cornerstone of the new stratifications and inequalities (Schierup 2007; Cillo, Perocco 2015). Such organisation of work - based on the differentiation of forms of employment and of work contracts in the same workplace for similar tasks has entailed new stratifications of the workforce and a sharp stratification in working conditions, which worsen the lower you get in the various levels of subcontracting. The situations vary according to the different degrees of precarity and exploitation within the applicative modes of subcontracting; this has dictated a new geography of working conditions and labour rights which, as regards migrant workers, spans a scale from decent regular work to forced labour, with intermediary steps such as undeclared work, severe labour exploitation, intermittent work, and casual work.

The transformations in the global labour market and in the organisation of work, together with the structural precarisation of work (which I will examine in the next section), have had several consequences, which include increased unemployment and underemployment, the trending reduction in wages, and more pronounced segmentation and polarization of employment (Goos et al. 2009; Huws 2003; OECD $2013,2014,2015)$. These events have affected the entire European working class, with more acute effects on migrants or those with a background of migration.

\section{THE STRUCTURAL PRECARISATION OF WORK}

As one of the core tenets of neoliberal policies, the process of the structural precarisation of work is a prerequisite and a carrier of the intensification of labour exploitation required by the rules of the global economic order in response to the constant decrease of accumulation rates and recurring economic crises, which are increasingly frequent and acute. The fracture in the unity of the labour contract, the destructuring of labour law, the introduction of a plethora of contract types with different conditions and rights - voucher, shared, on-call, zero-hour contract, voluntary, outsourced, subcontracted, posting of workers, freelancing, formally independent, formally cooperative work - are all part of a process which is broader and deeper than a mere reduction of guaranteed jobs. After a few decades, from the 1950s to the 1970s, which saw the attainment of relatively stable and secure jobs, a radical and extreme commodification of labour has taken place. 
The structural precarisation of work has several consequences: new stratifications, the growth in wage inequalities, the impoverishment of many groups of workers, the increase in the army of reserve labour (through the creation of a reserve within the reserve), the unconditional adaptation of workers' lives to the organisational needs of private companies and public bodies, the alteration of social rights which have been readjusted for the benefit of companies, and the deterioration of psychological and physical health as precarity corrodes people. Occasional, intermittent, shared, for rent, subcontracted, on-call work contracts and all other forms of work precarity (with its leader: irregular work, and its extreme: forced labour), at first applied among migrants, have fragmented and disconnected the labour force, enabling the general devaluation of labour and denying the role of workers in the production process. The consequences have been so dire that rather than describing this as simply commodification of labour, in extreme cases we should talk about nullification of labour and of the worker, for whom nothing is and nothing has to be guaranteed, who - exactly like migrants in racist representations - has to have zero rights.

With the recent economic crisis and the consequent radicalisation of neoliberal policies (Bauman 2013; Crouch 2011), labour precarisation has further expanded and deepened, with a leap in both quantity and quality, going beyond precarity as it was known in the recent past. Now, precarity 2.0 - vouchers, meal tickets instead of wages, serial internships, volunteering, unpaid work, zero-hour contracts, temporary work, posted workers, fake cooperatives - has transcended its boundaries, replacing a part of the "first generation" precarious jobs and becoming the norm. The precarisation of labour, both in its old and new version, has been unleashed on workers unevenly. The first, and most affected, were migrants, young people, lowskilled and low educated female workers with children, older workers affected by company restructuring, and low-skilled workers - i.e. those who constitute the most vulnerable segment of the European working class. This underclass, which does not constitute an individual class on its own, ${ }^{2}$ has experienced increased impoverishment and marginalisation; it is the subject of racist campaigns as regards its foreign component and of nationalist refrains as regards its native component.

\section{THE PRECARISATION OF MIGRATION AND THE RISE OF TEMPORARY MIGRATIONS}

The process of precarisation of migration which has taken place in Europe over the last two decades has affected both resident migrant populations and incoming migrants. The former have seen sharper and increasing mechanisms of exclusion, segregation and assimilation, while the latter have been welcomed by increasingly harsher selection and restrictive mechanisms.

2 As indicated by Standing (2011). 
The precarisation of migration is nothing new in the history of Europe, but in the last two decades this process has clearly radicalised. Several mechanisms and modes were involved, including the globalisation of restrictive migration policies and the encouragement of temporary migrations, the attribution to migration of a specific role in the labour market and within European economies, and the rise of racism and anti-migrant propaganda.

With reference to the first point, since they depend on the market, migration policies have incorporated the pronounced need of the economic system for flexible migrant workers, not too rooted, who may be used "just-in-time" according to the needs of production. The migration policies of European countries and the EU have learned the lesson of the dictates of the global market, aimed at the general devaluation of labour, and at low-cost globalisation, through a generalisation of stable precarity and the creation of global competition between workers at global level. They have affected the conditions of migration, of resident migrant populations (who now have to undergo a strict process of inclusion and exclusion) and new migrants towards Europe (with their severe restrictions in entry routes and prerequisites).

Migration policies - increasingly in the name of temporariness, militarisation and externalisation - have played a leading role in the process of precarisation of migrants. In several European countries migrant workers are subject to double precarisation, in both the work and legal spheres: while the former is included in the aforementioned casualisation, the latter is linked to the migration policies of many countries, which subordinate the migrants' right of abode to the existence of a work contract, and also tie their social rights to their migration status (thus stratifying social rights; Schierup et al. 2006; Morris 2002). The blanket requirement of having a work contract in order to obtain a residence permit during a period of structural economic crisis and casualisation puts migrants in a perilous and blackmail position, forcing them to accept whatever work conditions are offered.

In comparison with previous decades, the interaction between work casualisation and legal precarity has increased the precarisation of migrants' conditions. Torn between the rigidity determined by migration laws and the flexibility produced by labour laws, migrants have found themselves as new guest workers attempting to navigate a context of economic stagnation, characterised by the surge of atypical contracts and the general weakening of the labour movement. The process of the downward convergence of migration policies - starting slowly in the 1970s and 1980 s and gaining momentum in the 1990s and 2000s - has affected several European countries and has seen the confluence of the different migration policies into a single migration policy which is selective, restrictive, and repressive (Basso 2014), and which balances new migrant arrivals according to the needs of the labour market. Thus, if for the 1960s and 1970s we can talk about a relatively stable process of insertion into the labour market, in the following decades the reality is that of a precarisation of this process (Schierup et al. 2015), and, on the social level, the escalation of exclusion or segregation factors. 
Migration policies have also made new migration movements more precarious, especially through support for temporary migrations (seasonal, contract-based, circular, spontaneous and regulated migration). ${ }^{3}$ Through temporary migrations, European countries take advantage of the possibility to extract value from hyper-mobile migrant labour without the social implications deriving from the rooting of migrant populations and the social transformations brought about by immigration; they have a low-cost flexible workforce that reduces the social and political costs of immigration. The policies supporting temporary migration offer the market and the production system a mass of temporary workers, without their families, with few links to the host society, and with poor knowledge of the area they're working in; such policies create a mass of people who are forced to curtail their social needs and demands due to their temporary presence. These migration policies provide and entail a workforce offering the most sought-after element in the economic system: full availability.

In the last 15 years, we have witnessed a proliferation of public discourses, communications and official declarations, measures and bilateral agreements aimed at supporting or carrying out temporary migrations. This campaign saw the participation of several actors: the majority of European states, political parties, entrepreneurial associations, the press, opinion leaders and scholars. The European Union has played a leading role in this movement, ${ }^{4}$ drawing attention to circular migrations, supporting the creation of new and specific programmes, and feeding the debate on the advantages mobility partnerships should grant the receiving countries, the countries of origin and migrants. ${ }^{5} \mathrm{~A}$ political, institutional and administrative process was started which created several bilateral agreements, projects, mobility partnerships, and memoranda on temporary, circular, and seasonal migrations. In theory, it was supported by the paradigm of mobility, which qualifies and represents temporary migrations as "mobility" and not "migration". Such a paradigm considers the presence of the migrant worker as something temporary and transient, almost fleeting and ephemeral; it tends to eliminate the concrete category of "migration" and replace it with the more intangible, fluid, volatile category of "mobility". Gjergji notes that such replacement is not accidental, as the combination of bilateral agreements

3 It is hard to make a clear distinction between these types, it is easier to highlight their shared feature: migrations of precarious workers (Wickramasekara 2011).

4 Main documents: Communication from the Commission to the Council and the European Parliament. On a Community Immigration Policy of 22. 11. 2000; http://eurlex.europa.eu/LexUriServ/LexUriServ.do?uri=COM:2000:0757:FIN:EN:PDF); European Commission Communication on circular migration and mobility partnerships between the European Union and third countries of 16. 5. 2007, http://eur-lex.europa.eu/legal-content/EN/TXT/?uri=LEGISSUM:I14564.

5 Actually the advantages are only extended to the countries of origin, as temporary migrant workers have fewer chances to access rights and protections in the areas of work, healthcare, education, housing, and social security compared to those holding a residence permit and/ or a long-term work contract (or even citizenship); they have limited possibilities to change their job, to create associations, or to reunite their families; they are more exposed to workplace accidents and they generally enjoy less health and safety at work (Castles, Ozkul, 2014; Wickramasekara 2011). 
and circular migrations entails a migration model in which (strictly selected) migrant workers move following the production cycles, i.e. the short-term fluctuations of the market. This return to policies supporting temporary migrations goes beyond the traditional migration policies of the European Union and European countries, ${ }^{6}$ at the same time integrates their restrictive and repressive policies, which implies that the only legal entry route is temporary migration, and the institutionalization of precarity among migrant workers (Gjergji 2016: 58-60, 70).

The posting of workers is an example of the manifestation of the paradigm of mobility, as it often is not considered "migration" but rather "mobility". Even though this is questionable, it holds some truth, as the posting of workers is a symbol of work in the neo-liberal era: mobile workers, moved and used according to the immediate needs and restless activity of the market.

As regards the role of migration within European capitalisms, in the last decade the role of reserve armies of labour and social buffers against crises has intensified. Migrant workers have been the first group subjected to the shift to structural precarity and to the most extreme forms of labour precarity (occasional work, token work in healthcare, work paid with vouchers in agriculture). The operating mechanisms of the labour market - selection, concentration, and specialisation - have continued to channel a good share of migrant workers into the most precarious and poorly-paid jobs and sectors. Thus in a large part of Europe their working conditions - from access to work to unemployment, from tasks to wages, from classification to mobility - still reflect disparities compared to national workers. There are high levels of unemployment, under-employment, over-education, and atypical contracts, all of which have increased in percentage over time, and which have grown alongside the recent economic crises (OECD 2013b, 2015b). Such worsening is mainly linked to the shift from full-time contracts to (formally) part-time contracts, to the marked increase in temporary contracts and intermittent work, and to the drop, or the risk thereof, in irregular work or unemployment, forcing them to accept any conditions in order to keep their residence permit.

At the same time, migration has been a carrier of precarisation. It is (involuntarily) an agent of spreading and widening precarisation - often a testing ground where new forms of precarity are trialled before being extended to other groups of workers. The labour market is segmented, but it is also a system of communicating vessels: the spreading of precarity among migrant workers has been a factor in the general proliferation and expansion of precariousness. Within this framework, migration policies have played an important role in paving the way and anticipating corresponding labour laws.

6 "Both circular migration and mobility partnerships addresses a weakness in traditional immigration policies, namely that they have an inbuilt tendency to encourage migration to become permanent. This is because they do not tend to create the possibility for return" (Boswell, Geddes 2010: 96-97). 
In this context, where migration is encouraged by the labour market (for a very specific reason) and discouraged by state institutions with restrictive migration policies - according to an approach aimed at the social and political exploitation of migrants - the real purpose of this downward migration policy is not a complete stoppage of immigration, but rather an unstable, poorly rooted and vulnerable immigrant population, and a worsening of the conditions of migration, which serves as a general devaluation of labour.

Historically, the migrant labour force has been one of the main levers of the devaluation of the labour force as a whole. It has constituted a reserve workforce which supplied the needs of capitalist production by lowering the cost of labour and by offering an ultra-flexible workforce, owing to repressive migration policies, racism, and institutional discrimination (Potts 1990). Today, this specific condition of migration has turned it into a testing ground, a laboratory in which the manufacturing system has experimented with new forms of organising work - conceived of as a means of increasing profitability and productivity - which have led to replacing secure jobs with precarious ones, and to new stratifications of the labour market.

In this sense, migration policies and labour policies increasingly aimed at precarity have gone hand in hand. The creation of an institutionally weak and precarious proletariat, of an underclass of temporary workers replacing each other in constant rotation and circulation, has not only allowed the experimentation with new forms of labour exploitation to spread, but has also favoured a new global regulation of work relations and contracts in the name of stable precarity. The production of undocumented migrants - the culmination and the apotheosis of total precarity - is an integral part of the structural precarisation of labour.

As regards the rise of racism, institutional racism with its subtext of inferiorisation and stigmatisation has contributed to the precarisation of migrants' conditions, thus offering the market a mass of docile, available and obedient workers. The anti-immigration offensive has supported migration policies characterised by a mix of identity and security elements, and by the return of assimilationism. This neo-assimilationism, both in policy and rhetoric, has required maximum social adaptation by migrants to the conditions to which they are subjected. The mass media have created a racialised depiction of society and, at the same time, a differentiated representation of migrants, which is integral to their stratified precarity and to their differentiated exploitation. Unceasing denigration campaigns against various groups (the undocumented, Muslims, Romanians, second generation youth, neighbourhoods with high rates of migrants), have ended up affecting migration as a whole and subsequently a large share of the global labour market, dividing it along various lines of differentiation, such as in the dichotomies "good undocumented migrant workers" versus "bad undocumented migrant workers", "documented migrant workers" versus "undocumented migrant workers", "good documented migrant workers" versus "documented workers stealing our jobs", and "migrant workers" versus "national workers". Slogans and discourses, focused on a necessarily 
temporary presence, on a preference for national workers, and on a subordinated integration of migrants in the name of social inferiority, have paved the way for precarisation to affect the vast majority of migrants as a racialised class segment of the European working class.

\section{CONVERGENCES: POSTED WORKERS, AN EXAMPLE OF AND CARRIERS OF PRECARITY}

The posting of workers has increased in the last decade, ${ }^{7}$ though it has not become a mass phenomenon (European Commission 2016). Mainly known among insiders, often used in labour-intensive sectors or through the expanded use of subcontracting (Berntsen 2015; Thörnqvist, Bernhardsson 2015; De Wispelaere, Pacolet 2017), it may be a tool of social dumping (Cremers 2011; Fond. Brodolini, Cowi 2016; Lillie 2012). In this section I will present a set of considerations on the posting of workers, linked to the perspectives and arguments presented above. ${ }^{8}$

In the framework of the double dynamic of unification and segmentation of the global labour market, the posting of workers is the result of the convergence of several processes, in particular the transformations of work, the casualisation of labour and the precarisation of migration. The posting of workers is a limited phenomenon, but at the same time it is linked to several social dynamics, to a number of nexuses which shall be considered globally both at analysis and policy level, in order to avoid biased analyses or limited interventions.

The posting of workers is not only an example of the global process of the structural casualisation of work: it is also a carrier through which such process takes place, an instrument for the further expansion and intensification of contract precarity and work flexibility (Idea Consult, Ecorys 2011: 12). It matches and supports the spread of atypical contracts to wider groups of workers and the increase in the flexibility of the organisation of work. Subcontracting is an iconic example: in the different levels of the subcontracting system, posted workers are often employed, which leads to the further expansion of outsourcing and subcontracting.

Precarisation is a continuum, and as such it presents varying degrees of precarity: at one extreme we find maximum stability, a worker with a full-time contract; at the other pole we find maximum instability, embodied by a migrant worker with no contract and no residence permit (the undocumented migrant, the epitome of precarity); in between there are different situations and degrees. Posted workers are often located on the instability side of this spectrum (Berntsen 2015; Cillo 2017; Cremers 2011; Danaj 2017; Lillie 2012), yet the situations vary according to the combination of a number of factors, such as the type of employment contract, the size

7 For an updated review see Voss et al. 2016.

8 Here I refer to low-skilled workers, and not to officials or high-skilled managers. 
of the sending company and of the receiving company, the tasks, the employment sector, and the country of destination.

The posting of workers is one of the several mechanisms of differential exploitation of labour. In this case, subcontracting is again a good example: it resorts to different groups of workers - full-time or temporary workers at the parent company, at contracting and subcontracting companies, cooperative workers, posted workers, irregular workers - who experience differentiated working conditions, with different and stratified rights. From the perspective of civic stratification, the posting of workers is an integral part of the global process of the alteration of social rights which has been going on for at least several decades; especially in cases of abuse, it is a vector for the corrosion of social rights and the basis of an increasingly disparate social citizenship with variable geometry.

The posting of workers is a sort of "hidden migration" in two senses. From a formal point of view, migration is being replaced, as previously mentioned, by the notion of mobility, so much so that a posted worker often is not considered a migrant worker, not even an old-fashioned Gastarbeiter, but rather a mobile, fluid, justpassing-through worker. From a practical point of view, the social nature of posted workers makes them barely rooted and included in the local society, poorly included in the framework of industrial relations, barely using the services of the area, barely in touch with trade unions and associations, segregated in their workplace, and very weak in relation to their employers. ${ }^{9}$ Their temporary nature and mobility make them invisible: invisible to the receiving society, caught in a condition of social apnea with regard to their impending return, of social suspension, of absence in presence. ${ }^{10}$

The posting of workers is an empirical space of social research that includes different dimensions of analysis, including the very important yet little studied sector of occupational safety and health (Rogelja, Toplak 2017). At times, researchers have examined the posting of workers under the sole point of view of labour legislation or labour studies, casting a shadow on the migration dimension and experience; at other times, the opposite has been true, when scholarship on migration prevailed. We need to blend both perspectives, in order not to lose sight of the transformations of work or migration dynamics. ${ }^{11}$ Furthermore, to carry out an across-the-board analysis, we need to consider the macro level (medium- and long-term global processes), the meso level (e.g. national and supranational policies), and the micro level (single local experiences, in a given moment and specific context) which comprise the phenomenon of the posting of workers.

9 It is no accident that we are lacking data on the phenomenon, and that many countries have a hard time detecting and monitoring it.

10 In this respect, Sayad's work on the indefinite provisional, the double absence, and noria, is more useful and current than ever (Sayad 1999).

11 Cf. Danaj 2017. 


\section{CONCLUSION}

Work casualisation and the precarisation of migration may be considered two different processes which can converge and produce effects, but the precarisation of migration may also be intended as an internal dynamic of work casualisation, which falls within the wider process of precarisation of labour. In either case: 1) work casualisation has made a quantum leap in quality and quantity, overcoming the classic form used in the past few years and now reaching extreme forms; 2 ) such leap has affected first and foremost migrant workers, but it happened in parallel with the levelling down of the conditions of workers, increasingly often sharing the same conditions, though in different ways; 3 ) in the case of migrant workers, precarity has its own specificity, while at the same time it has always been a feature of the world of labour; 4) the analyses, policies, interventions and protection actions should always consider this duality - specificity and generality - in order not to lose sight of the specificities of the migrant condition and, at the same time, the general condition of all workers, both nationals and foreigners.

The precarity affecting migrant workers is a powerful tool of exclusion or segregation, as the exercise of social rights is often subordinated to a work contract or residence permit. The return of the guest worker - in a context of flexible capitalism, with all its fragmentation and polarization - and the increase in temporary migrations have favoured, in an era of structural precarity, rising racism in the name of the welfare state (Burnett 2015), limited and restricted acquisition of social rights, and the creation of new forms of inequality and stratified rights. The attack on social citizenship has used the world of immigration as one of its starting points, but it has not been confined to this sector and has in fact been extended to other layers of the population.

Posted workers, as explained, find themselves at a crossroads between several social processes, which they also represent: they are an example of the global competition created among workers on the global labour market; they respond to the transformations of work and the demand of selected workforce, which has to be mobile and usable in a just-in-time fashion. They are embodied by the temporary worker, with their body in the receiving country and their mind in the country of origin, with no social rooting. Such a "bird of passage" of the new millennium is often an invisible physical presence - in their job, in their relations with their employer, in their fear of being "discovered" as posted workers, who over time consider themselves "semi-illegals" or "almost illegals".12 For this reason, among all the features of the posting of workers, the most relevant matters to consider will be their presence, visibility, self-image, voice, activation, organisation, and representation. All these matters will require attentive and in-depth analysis in the near future.

12 This aspect emerged from empirical research carried out in Italy and Belgium within the Poosh project on occupational safety and health of posted workers (http://www.poosh.eu). 


\section{REFERENCES}

Antunes, Ricardo (2008). Desenhando a nova morfologia do trabalho. Revista Critica de Ciências Sociais 1, 19-34.

Antunes, Ricardo (2013). The Meanings of Work. Leiden-Boston: Brill.

Basso, Pietro (2014). Neoliberalism, Crisis and International Migration. Polarizing Development (eds. Lucia Pradella, Thomas Marois). London: Pluto Press, 86-97.

Bauman, Zigmunt (2013). Does the Richness of the Few Benefit Us All? Cambridge: Polity Press.

Berntsen, Lisa (2015). Precarious Posted Worlds: Posted Migrant Workers in the Dutch Construction and Meat Processing Industries. The International Journal of Comparative Labour Law and Industrial Relations 31/4, 371-390.

Boswell, Christina, Geddes, Andrew (2010). Migration and Mobility in the European Union. London: Palgrave.

Burnett, Jon (2015). The War on Welfare and the War on Asylum. Race and Class 57/2, 96-100.

Castles, Stephen, Ozkul, Derya (2014). Circular Migration, Triple Win or a New Label for Temporary Migration? Global and Asian Perspectives on International Migration (ed. Graziano Battistella). New York: Springer, 27-36.

Cillo, Rossana (2017). Posting of Workers in the Construction Sector: An European Overview. Occupational Safety and Health of Posted Workers (eds. Nataša Rogelja, Kristina Toplak). Ljubljana: ZRC Publishing House, 16-21, http://zalozba.zrc-sazu. si/p/1451 pdf. (18. 11. 2017).

Cillo, Rossana, Perocco, Fabio (2015). Sous-traitance et exploitation différentielle des travailleurs immigrés. Travail, Emploi, Formation 13, 84-103.

Cremers, Jan (2011). In Search of Cheap Labour in Europe: Working and living Conditions of Posted Workers. Bruxelles: CLR, http://www.clr-news.org/CLR-Studies/Websummary.pdf (24. 6. 2017).

Crouch, Colin (2011). The Strange Non-Death of Neoliberalism. London: Polity Books.

Danaj, Sonila (2017). Health and Safety Implications of Posted Work: The Example of British Engineering Construction. Occupational Safety and Health of Posted Workers (eds. Nataša Rogelja, Kristina Toplak). Ljubljana: ZRC Publishing House, 11-15, http://zalozba.zrc-sazu.si/p/1451 pdf. (18. 11. 2017).

De Wispelaere, Frederic, Pacolet, Jozef (2017). The Size and Impact of Intra-EU Posting on the Belgian Economy: With a Special Focus on the Construction Sector. Leuven: HIVA, https://lirias.kuleuven.be/bitstream/123456789/577669/1/ The+size+and+impact+of+intra-EU+posting+on+the+Belgian+economy.pdf (22. 10. 2017).

Doogan, Kevin (2009). New Capitalism? The Transformation of Work. Cambridge: Polity Press. 
European Commission (2016). Posting of Workers. Report on A1 Portable Documents Issued in 2015, http://ec.europa.eu/social/BlobServlet?docld=17164\&langld=en (22. 10. 2017).

Ford, Martin (2015). Rise of the Robots: Technology and the Threat of Mass Unemployment. New York: Basic Books.

Fond. Brodolini, Cowi (2016). Study on Wage Setting Systems and Minimum Rates of Pay Applicable to Posted Workers in Accordance with Directive 96/71/EC in a Selected Number of Member States and Sectors, http://ec.europa.eu/social/BlobServlet?do$c l d=14966 \&$ langld $=e n$ (22. 10. 2017).

Gjergji, Iside (2016). Sulla governance delle migrazioni. Milan: Franco Angeli.

Goos, Maarten et al. (2009). Job Polarization in Europe. American Economic Review $99 / 2,58-63$.

Head, Simon (2003). The New Ruthless Economy. New York: Oxford University Press. Huws, Ursula (2003). The Making of a Cybertariat. New York: Monthly Review Press.

Huws, Ursula (2014). Labor in the Global Digital Economy. New York: Monthly Review Press.

Huws, Ursula, Podro, Sarah (2012). Outsourcing and the Fragmentation of Employment Relations: The Challenges Ahead. Acas, http://www.acas.org.uk/media/pdf/p/8/ Outsourcing-and-the-fragmentation-of-employment-relations-the-challenges-ahead.pdf (24. 9. 2017).

Idea Consult, Ecorys (2011). Study on the Economic and Social Effects Associated with the Phenomenon of Posting of Workers in the European Union. Brussels: European Commission, http://ec.europa.eu/social/BlobServlet?docld=6678\&langld=en (15. 9. 2017).

Lillie, Nathan (2012). Subcontracting, Posted Migrants and Labour Market Segmentation in Finland. British Journal of Industrial Relations 50/1, 148-167.

Morris, Lydia (2002). Managing Migration: Civic Stratification and Migrants Rights. London: Routledge.

OECD (2013). Crisis Squeezes Income and Puts Pressure on Inequality and Poverty, http:// www.oecd.org/social/inequality.htm (11. 5. 2017).

OECD (2013b). International Migration Outlook 2013, http://www.oecd-ilibrary.org/social-issues-migration-health/international-migration-outlook-2013_migr_outlook-2013-en (11. 5. 2017).

OECD (2014). Focus on Inequality and Growth, http://www.oecd.org/social/inequality-and-poverty.htm (11. 5. 2017).

OECD (2015). In It Together: Why Less Inequality Benefits All, http://www.oecd.org/ social/in-it-together-why-less-inequality-benefits-all-9789264235120-en.htm (11. 5. 2017).

OECD (2015b). International Migration Outlook 2015, http://www.oecd-ilibrary.org/ social-issues-migrationhealth/international-migration-outlook-2015_migr_ outlook-2015-en (11. 5. 2017). 
Potts, Lydia (1990). The World Labour Market: A History of Migration. London: Zed Books.

Rogelja Nataša, Toplak, Kristina (2017). Mobility, Flexibility and Vulnerability. Occupational Safety and Health of Posted Workers (eds. Nataša Rogelja, Kristina Toplak). Ljubljana: ZRC Publishing House, 5-10, http://zalozba.zrc-sazu.si/p/1451 pdf. (18. 11. 2017).

Sayad, Abdelmalek (1999). La double absence. Paris: Seuil.

Schierup, Carl-Ulrik (2007). 'Bloody Subcontracting' in the Network Society: Migration and Post-Fordist Restructuring across the European Union. Irregular Migration, Informal Labour and Community (eds. Erik Berggren et al.). Maastricht: Shaker, 150-164.

Schierup, Carl-Ulrik et al. (eds.) (2006). Migration, Citizenship, and the European Welfare State. Oxford: Oxford University Press.

Schierup, Carl-Ulrik et al. (eds.) (2015). Migration, Precarity, and Global Governance: Challenges and Opportunities for Labour. Oxford: Oxford University Press.

Standing, Guy (2011). The Precariat. London, New York: Bloomsbury.

Thörnqvist, Chister, Bernhardsson, Sebastian (2015). Their own Stories - how Polish Construction Workers Posted to Sweden Experience their Job Situation, or Resistance versus Life projects. Transfer 21/1, 23-36.

Voss, E. et al. (2016). Posting of Workers Directive - Current Situation and Challenges. Brussels: European Parliament, http://www.europarl.europa.eu/RegData/ etudes/STUD/2016/579001/IPOL_STU\%282016\%29579001_EN.pdf (13. 9. 2017). Weil, David (2014). The Fissured Workplace. Cambridge: Harvard University Press.

Wickramasekara, Piyasiri (2011). Circular Migration: A Triple Win or a Dead End? Geneva: ILO, http://www.migration4development.org/sites/m4d.emakina-eu.net/files/ no15-mar11-circular-migration-a-triple-win-or-a-dead-end.pdf (27. 10. 2017). 


\section{POVZETEK}

\section{NAPOTENI DELAVCI MED KAZUALIZACIJO DELA IN PREKARIZACIJO MIGRACIJ \\ Fabio PEROCCO}

Med družbenimi spremembami in spremembami na področju dela na globalni ravni izstopata kazualizacija dela in prekarizacija migracij. Strukturna prekarizacija dela, ki je povzročila radikalno komodifikacijo delovnih razmerij, se je med ekonomsko krizo še poglobila in presegla prekarne zaposlitve "prve generacije«, prizadela pa tako stalno naseljene migrantske delavce kot prihajajoče migrante. Prvi so doživeli ostrejše mehanizme izključevanja, drugi pa strožjo selekcijo in restriktivne mehanizme.

Prekarizacija migracij se kaže v globalizaciji restriktivnih migracijskih politik, spodbujanju začasnih migracij, povezovanju migrantov z določenimi vlogami na trgu dela in vzponu rasizma. Vodilno vlogo pri tem so odigrale migracijske politike, v številnih evropskih državah so migrantski delavci podvrženi dvojni prekarizaciji: pri samem delu in v zakonodaji. Razpeti med togost migracijske in fleksibilnost delovne zakonodaje so $v$ kontekstu fleksibilnega kapitalizma in ekonomske stagnacije čez noč postali gostujoči delavci. Ponekod je povzročil zlitje različnih migracijskih politik v eno samo selektivno, restriktivno in represivno migracijsko politiko.

Kazualizacija dela in prekarizacija migracij se pogosto povezujeta in prepletata, kar prispeva k rasti začasnih migracij. Napoteni delavci so primer strukturne kazualizacije dela ter podlaga za pogodbeno prekarnost in delovno fleksibilnost. Napotovanje delavcev je mehanizem diferencirane eksploatacije dela, saj so prav napoteni delavci deležni različnih delovnih razmer in stratificiranih pravic. Napotovanje je del globalnega procesa spreminjanja družbenih pravic še zlasti v primerih zlorabe.

Napotovanje delavcev je oblika »skrite migracije«. Migracijo je v formalnem smislu nadomestil pojem mobilnosti; napotenega delavca se ne obravnavana kot migranta, temveč kot mobilnega, fluidnega delavca v stalnem gibanju. Zaradi svoje družbene narave je slabo povezan z lokalnim okoljem, s sindikati in z združenji, zaradi česar v večinski družbi neviden lebdi v nekakšni družbeni apneji. 